\title{
The Practice of Usrah in Teaching and Learning: Case Study at the International Islamic University Malaysia
}

\author{
AWANG ABDUL MUIZZ AWANG MARUSIN*, SURAYA SINTANG \\ \& MOHD. AZRI IBRAHIM ${ }^{1}$
}

\begin{abstract}
The purpose of this study is to analyse Usrah Mahallah in the International Islamic University Malaysia (IIUM), application of usrah therein and its contributions in improving teaching and learning approaches. As the focus of this study is much qualitative, a case study was conducted and so become the only method that can realise the purpose of this study. Findings shown that Usrah Mahallah is widely accepted by IIUM resident students participated in usrah. Small ratio of usrah leader to usrah participants, contemporary and friendly approaches applied by usrah leaders, organisation of attractive Usrah activities at both residential college and IIUM levels and flexibility and conduciveness of usrah settings established and maintained jointly by Usrah leaders and participants are among key factors that contributed to such acceptance. Those findings lead to the fact that Usrah Mahallah is not only a progressive product of Islamisation in IIUM and a tool to develop students' social, spiritual and intellectual values and skills, but also an effective approach to teaching and learning, especially in Islamic education.
\end{abstract}

Keywords: education, Islamic education, International Islamic University Malaysia, teaching and learning, Usrah

In order to be an international Islamic centre of educational excellence, the International Islamic University Malaysia (IIUM), established on 23 May 1983 (Zaleha \& Abdul Rashid 2013: 4), outlines a number of missions, which is later summarised into IIICE (Triple ICE), which stands for Integration, Islamisation, Internationalisation and Comprehensive Excellence (IIUM 2015: 2-4). Although Islamisation stands equal with three other principles of Triple ICE, Islamisation continues to stand as the most important foundation of Islamic education in Malaysia and so as that of IIUM.

A lot of efforts have been done by IIUM community in order to maintain the status quo of Islamisation in IIUM. One of those efforts is usrah, which many Malaysians claimed as an Islamic family comprising Muslim parents and children practicing Islamic lifestyle, and yet the literal definition of usrah, an Arabic word, is just family, i.e. parents and children (Ibrahim et al. 2015: 165). Unfortunately, Malaysian education history have not confined the definition of usrah just there.

The establishment of Ikhwan al-Muslimin in Egypt in 1928 had not only influenced Muslim community in Malaysia, but also had founded one of contemporary - and yet effective, as

\footnotetext{
${ }^{1}$ Awang Abdul Muizz Awang Marusin*(corresponding author), postgraduate student at Centre for the Promotion of Knowledge and Language Learning, Universiti Malaysia Sabah, 88400 KOTA KINABALU, Sabah, Malaysia email: aamuizz@gmail.com; Suraya Sintang, Ph.D., senior lecturer at Centre for the Promotion of Knowledge and Language Learning, Universiti Malaysia Sabah, 88400 KOTA KINABALU, Sabah, Malaysia email: surayasin12@gmail.com; Mohd. Azri Ibrahim, Ph.D., senior lecturer at Centre for the Promotion of Knowledge and Language Learning, Universiti Malaysia Sabah, 88400 KOTA KINABALU, Sabah, Malaysia, email: mohdazri@ums.edu.my.
} 
recognised by Sidek (1991) and Ab. Halim (2010) - Islamic education approaches in Malaysia called usrah. Since then, usrah can be understood as an Islamic study circle that promotes the pursuit of knowledge and the sharing of life experience in a more familiar and friendly environment (Ibrahim et al. 2015: 165).

Trager (2011) described usrah in Ikhwan al-Muslimin as a small group consisting of four to five people whose roles are to support the promotion of the organisation's ideology and to provide spaces and opportunities to members to share their life and to strengthen members' mental and spiritual. The same concept has been applied by the International Islamic University Malaysia (IIUM).

Since its establishment, IIUM introduced usrah, a formalised informal education that enables students to share experiences and ideas on their daily life and the state of Islam and the Muslim Ummah. The inception of usrah in IIUM does not only widen the opportunity of dakwah in IIUM, but also show a new way of enhancing education in the 21st century.

\section{About the Study}

This is a qualitative study that intends to explain Usrah Mahallah in IIUM, analyse usrah as a method of teaching and learning in IIUM residential colleges, justify the role of usrah in shaping the future of education. These objectives, at the end of this study, will not only demonstrate the role of IIUM residential colleges in supporting academic activities in IIUM schools of studies, but also their contributions towards the development of teaching and learning in the 21st century.

This qualitative study is made possible through a case study that is established using two ways. The first is IIUM Usrah Mahallah 2016/2017 Annual Report, which was initially administrative but, as suggested and done by experts in usrah, turned academic (Nik Md. Saiful Azizi et al. 2017), and the second is an observation conducted by a group of IIUM Usrah Mahallah steerers towards an usrah sessions done in at least six residential colleges in IIUM Gombak Campus in April 2017.

As usrah in IIUM have three segments as at 30 June 2018, this study will be confined to Usrah Mahallah. As Usrah Mahallah has taken place at IIUM Gombak Campus and IIUM Centre for Foundation Studies, this study will be limited to Usrah Mahallah at IIUM Gombak Campus only. It is due to the fact that Usrah Mahallah was initiated at IIUM Gombak Campus and that the centre of Usrah Mahallah has been at the same campus since its initiation.

\section{IIUM Usrah Mahallah}

Ibrahim et al. (2015: 168) describes usrah in IIUM as a co-curricular activity that enables students to share their daily life as a Muslim and idea on the state of Muslim ummah at present time with their varsity mates. Sri Rahmayana et al. (2016: 180) further describes that usrah in IIUM comes with three aims: to increase students' commitment towards Islamic lifestyle based on al-Quran and al-Sunnah, to generate the spirit of Islam beyond individual and cultural identities, and to enable students to understand different aspects of social reality.

Since 2017, Usrah in IIUM has three categories. The first one is usrah itself, which has been widely known as Study Circle and Halaqah (Nik Md. Saiful Azizi \& Sri Rahmayana 2016: 150-151). It is a credited and structured co-curricular programme that is made compulsory to first-year undergraduate students for one or two normal semesters. Each semester comprises of ten sessions of halaqah conducted by facilitators appointed by IIUM, usually among postgraduate students. Since 2017, it was known as Usrah BUDI.

The second one is Usrah for staff. The idea of organising usrah for IIUM staff members came from IIUM Rector, Professor Dr. Zaleha Kamaruddin, but was only made a reality in 2016 and continues until today. The purpose of Usrah for Staff is almost the same with two other categories of usrah; only target and modus operandi are different. Usrah for Staff is done once per 
month, usually at the University Mosque, and is compulsory for IIUM non-academic staff members. They are divided into groups of 10 members; each group is led by either an academician or a non-academic staff from professional and management group appointed by IIUM Usrah for Staff Committee.

The third one, which reflects the subject matter of this study, is Usrah Mahallah which represents a continuation from a centralised halaqah (IIUM 2017). It took place in the early years of IIUM but was later halted due to unforeseen circumstances. Thanks to the effort of IIUM Student Affairs and Development Division and IIUM Council of Principals of Residential Colleges, Usrah Mahallah was rejuvenated in 2014 and continues to take place in all 16 residential colleges in IIUM Gombak Campus. Learning from the success of Usrah Mahallah in IIUM Gombak Campus, Usrah Mahallah was expanded to IIUM Centre for Foundation Studies in 2017.

Usrah Mahallah comes with three main objectives. The first and the main objective is to provide IIUM resident students with an opportunity to pursue knowledge, share experience and enhance friendship and brotherhood in a harmonious way. The other two are to enliven the role of residential colleges (called "Mahallah" in singular or "Mahallat" in plural) as a centre of Islamic development for members of IIUM community, and to allow Islamisation to take place in all IIUM residential colleges where Islamic lifestyle and culture can be established and sustained in all Muslims individually and collectively.

Second-year undergraduate students residing in any mahallah in IIUM are obliged to participate in Usrah Mahallah and so to attend six sessions of Usrah Mahallah conducted by Naqib (Nuqaba' in plural) appointed by the respective Mahallah (Nik Md. Saiful Azizi 2017). Throughout those sessions, participants are expected to discuss with their respective naqib on topics provided by Nuqaba' Council in a compilation of topics called Usrah Manual.

As at 2017, Usrah Manual contains two modules which represents two different levels of usrah. Module One, entitled "Knowing Ourselves", is meant for Level One participants who are second-year first-semester students. Module Two, at the other side, entitled "Values of Life", is meant for Level Two participants who are second-year second-semester students. While Module Two focuses directly on six of 47 moral values to be applied in daily life as an individual and as a community of Malaysian people, as outlined by Malaysia (2014: 30-33), Module One touches on foundations of Islam and obligations as a Muslim.

\section{Usrah, Teaching and Learning}

Usrah is one of classical approach of education, as stated by Osman (2011: 49) and Ahmed (2013). This is due to the fact that it was initiated during the early apostolic era of Prophet Muhammad SAW and remains a main institution of learning organised in mosque and in small size until 11th century. The tradition was, however, continued by Ikhwan al-Muslimin during its existence as an influential Muslim organisation in Egypt.

The presence of Ikhwan al-Muslimin in Egypt brought a clearer setting of usrah. Trager (2011) described that an usrah group comprises of a leader and up to five members and that usrah remains for spiritual purpose. But the expansion of usrah to Malaysia in 1950s, and its practice after that, does not make usrah only spiritual, but also social. A number of Muslim people's institutions have proven such fact (Ahmad Luqman Fahmi \& Nik Suhaida 2015) and so have proven IIUM. This is in line with three principles of usrah outlined by Ikhwan al-Muslimin, which are Ta 'aruf (knowing each other), Tafahum (understanding each other) and Takaful (helping each other) (Mohammad Aatdiff 2017: 37-48).

Usrah Mahallah in IIUM is like two other categories of usrah in IIUM which is social and spiritual in nature and comprises of a small number of members. In Academic Year 2016/2017, around 300 usrah groups were formed in all 16 Mahallat of IIUM Gombak Campus. Each group is led by a Naqib appointed by the respective Mahallah and is attended by at least eight and not more than sixteen members. They did not only discuss on topics provided by Usrah Manual, but 
also organise activities related to the content of Usrah Manual. Consequently, more than 70 percent of overall participants managed to attend at least three of six usrah sessions required in each semester (IIUM 2017). This is in addition to encouraging and supportive comments from participants towards Usrah Mahallah (Nik Md. Saiful Azizi et al. 2017).

Four factors have supported these records. The first one is small ratio of usrah leader to usrah participants. Although Pedder (2006: 231) suggested that the small teacher-student ratio has less contributions to students' achievement, small ratio of leader to participants recorded at the end of Academic Year 2016/2017, which is one to nine (1: 9), made usrah sessions and activities for both leaders and participants more convenient. Because of small ratio, a leader is able to conduct and control discussions, sharings and instructional tasks in an usrah session. A participant, at the other side, managed to follow all deliberations of his respective leader in an usrah session and was able to understand lessons taught in such session.

The second factor is friendly and modern methods applied by usrah leaders. Although the approaches of usrah are initially traditional (Ibrahim et al 2015: 167), some of usrah leaders were found succeeded in using current and updated information and communication technology to conduct Usrah Mahallah sessions and so in facilitating the receipt of easy and effective messages by participants. This factor has, in researchers' opinion, turned usrah, which was initially traditional, to a contemporary method of teaching and learning.

The third factor is the organisation of attractive activities at both university and mahallah levels. IIUM reported that at least four centralised Usrah Mahallah activities took place successfully throughout Academic Year 2016/2017. Those activities, however, do not include a number of Usrah Mahallah activities done at mahallah level, like Slaughtering Practical and Rewang organised by Mahallah as-Siddiq and Islamic public speaking competition organised by Mahallah Safiyyah in collaboration with Majlis Dakwah Negara. The organisation of those activities enabled the practical deliberation of Usrah Mahallah content.

The fourth (and the most amazing) factor is conduciveness of environment created jointly by usrah leaders and participants. In the other words, Usrah Mahallah does not limited to the respective residential college only, but also organised in other places around the university campus, only participants come from such residential college. Usrah Mahallah, even though was scheduled only for every Thursday, between Maghrib and Isyak prayer time, is organised at a flexible time to make participants convenient to come to and participate in a session of Usrah Mahallah together. These kinds of flexibility have caused the message of Usrah Mahallah be conveyed in a comfortable condition.

\section{Usrah and the Future of Education}

At present, the way IIUM should achieve its vision through its missions is explained in IIUM Strategic Plan 2013-2020 (IIUM 2013: 15). Although Usrah Mahallah is not a part of it, Usrah Mahallah has contributed to three out of eight key results areas outlined therein. The direction of Usrah Mahallah reflects the contribution of Usrah Mahallah towards Islamisation, while the target and framework of Usrah Mahallah established jointly by staff members and students represents its contribution towards Holistic Student Development. Not to be forgotten is the content of Usrah Mahallah and the way it is delivered to the target group has contributed to quality teaching and learning.

More than that, Usrah Mahallah is found contributed to the improvement of teaching and learning approaches. This study proves that usrah leaders are guides instead of instructors, that usrah groups established conducive and pleasant environment successfully, and that usrah leaders and participants uses updated technology during and outside usrah sessions and activities.

Those proves are in line with three features of 21st century learning as suggested by Ondrashek (2017: 4-12), which are teacher as a guide, conducive and pleasant classroom 
environment, and updated technology. These are also in line with standards provided by Malaysian Ministry of Education (MOE). Under the Second Wave of Malaysian Education Quality Standard, teachers, as leader of teaching and learning, is required to be planner, controller, guide, encourager and assessor of students who are, at the other side, expected to be active learners (MOE 2017: 62-69).

In brief, usrah represents a method of teaching and learning that meets the people's need in the 21st century, especially Muslim ummah. Usrah, given its contributions to educational thought, social development and spiritual enhancement, can be regarded as an effort that enlighten the future of education in Muslim world, particularly Malaysia.

\section{Contributions of Usrah to IIUM and Islamic Education in Malaysia}

The findings demonstrated by the researchers do not only mention the importance and contribution of usrah to IIUM and Muslim education in Malaysia, but brings positive implications to all of them at the same time. At IIUM level, given the significant state of Usrah Mahallah, usrah is placed as a progressive product of Islamisation in IIUM. The success of Usrah Mahallah in 2016 has caused IIUM administration to introduce Usrah for Staff, the third of three usrah education types available in IIUM, in the following year.

The reason is crystal clear and signifies another positive implication; that is the promotion of supplementary social, spiritual and intellectual values. Through usrah, those values are not only disseminated by a leader to his members, but also shared among each other and even inter groups. The dissemination and sharing of those values will not only harmonise brotherhood and friendship created and maintained in usrah, but will also harmonise usrah itself and its direction.

At a higher level, while usrah is accepted as a contemporary method of teaching and learning, usrah has contributed to a better future of education to many extents, especially Islamic education. Through usrah, ideas and experiences that are shared among people, the importance and values of better state of education are promoted as well. The enhancement of approach of teaching and learning and the development of educational thought, through usrah, will not only harmonise the community, but will also help the present community to inculcate much more moral, spiritual and intellectual values in the future community.

To conclude, this study does not intend to bring drastic change to the state of Malaysian education at all levels, but rather to showcase the state of usrah as a successful trademark produced by IIUM which has directly and indirectly influence education community, i.e. students, teachers at schools and academicians at higher education institutions, as well as to synthesise the fact that usrah, given its contributions to teaching and learning and educational thought, represents the future of education. Unfortunately, usrah cannot be the only product that enhance teaching and learning.

The Muslim world are, therefore, recommended not only to develop and enhance usrah, but also to make usrah education a new type of education in their respective community and to explore other ways and means that will brighten the future of education, especially for the Muslim world and the Muslim ummah. This is to maintain Islam as a religion that produces great contributions to educational development all over the time.

\section{References}

Ab. Halim Tamuri. 2007. Islamic Education Teachers' Perceptions of Teaching of Akhlaq in Malaysian Secondary Schools. The Journal of Moral Education. 36: 371-386.

Ahmad Luqman Fahmi Abdul Fattah \& Nik Suhaida Nik Abdul Majid (2015). Usrah sebagai Medan Pembangunan Insan: Satu Analisis terhadap Perkembangannya di Malaysia. In. 
Mohammad Aatdiff Ahmat. 2017. Sejarah Usrah (pp. 49-86). Seri Kembangan: Ahlamuna Publication.

Ahmed, F. 2013. Exploring Halaqah as Research Method: A Tentative Approach to Developing Islamic Research Principles within a Critical 'Indigenous' Framework. International Journal of Qualitative Studies in Education. 40(2): 561-583.

Ibrahim, N.; Kasmani, S. R. \& Champe, J. 2015. Understanding the Islamic Concept of Usrah and Application of Group Work. The Journal for Specialists in Group Work. 40(2): 163-186.

International Islamic University Malaysia. 2013. IIUM 2013-2020 Strategic Plan: Premier Global Islamic University. Kuala Lumpur: International Islamic University Malaysia.

International Islamic University Malaysia. 2015. Memorandum and Articles of Association of International Islamic University Malaysia.

International Islamic University Malaysia. 2017. IIUM Usrah Mahallah 2016/2017 Annual Report. Malaysia. 2014. Nilai-nilai Murni dan Budi Bahasa. Malaysian Department of Information.

Malaysian Ministry of Education. 2017. Standard Kualiti Pendidikan Malaysia Gelombang Kedua. Putrajaya: Malaysian Ministry of Education.

Mohammad Aatdiff Ahmat. 2017. Sejarah Usrah. Seri Kembangan: Ahlamuna Publication.

Nik Md. Saiful Azizi Nik Abdullah. 2017. Introduction to IIUM Usrah Mahallah. Lecture presented at Training of Usrah Mahallah 2016/2017. 13 October. Gombak, Selangor, Malaysia.

Nik Md. Saiful Azizi Nik Abdullah, Nafi @ Hanafi Dollah \& Awang Abdul Muizz Awang Marusin. 2017. Development of Students' Character through Usrah Education as Lifelong Learning: Case Study in the International Islamic University Malaysia. International Conference on Lifelong Learning in Islamic Education 2017. 4-5 September. Nilai, Negeri Sembilan, Malaysia. (Unpublished).

Nik Md. Saiful Azizi Nik Abdullah \& Sri Rahmayana Syam. 2016. Perceived Learning Motivation and Learning Strategy among Study Circle (Halaqah) Students in IIUM. In, Ramdane, T. (ed.), The Curriculum of Islamic Education: Theoretical and Practical Challenges (pp. 143174). Kuala Lumpur: Institut Terjemahan dan Buku Malaysia.

Ondrashek, N. 2017. 21st Century Learning. Masters Thesis. Northwestern College.

Osman Bakar. 2011. The Role of Islam in Higher Education Policies of Muslim Countries. In Bakar, Osman; Winkel, Eric \& Amran, Airulamri (eds.). Contemporary Higher Education Needs in Muslim Countries: Defining the Role of Islam in 21st Century Higher Education (pp. 21-38). Kuala Lumpur: International Institute of Advanced Islamic Studies.

Pedder, D. 2006. Are Small Classes Better? Understanding Relationships between Class Size, Classroom Processes and Pupils' Learning. Oxford Review of Education. 32(2): 213-234.

Sidek Baba. 1991. The Malaysian Study Circle Movement and Some Implications for Educational Development. Doctoral Thesis. Northern Illinois University.

Sri Rahmayana Syam, Nik Md. Saiful Azizi Nik Abdullah, \& Kamal J. I. Badrasawi. 2016. Motivational Orientations and Learning Strategies among Undergraduate Students in Study Circle Courses. Asian Social Science. 12(6): 179-187.

Trager, E. 2011. September-October. The Unbreakable Muslim Brotherhood: Grim Prospects for a Liberal Egypt. Foreign Affairs. September/October Issue. 90 (5).

Zaleha Kamaruddin \& Abdul Rashid Moten. 2013. International Islamic University Malaysia: The University with a Soul. In, Zaleha Kamaruddin and Abdul Rashid Moten (eds.). IIUM: The Premier Global Islamic University (pp. 3-21). Kuala Lumpur: International Islamic University Malaysia. 